\title{
Dye tracing to determine flow properties of hydrocarbon-polluted Rabots glaciär, Kebnekaise, Sweden
}

\author{
C. C. Clason ${ }^{1}$, C. Coch $^{1}$, J. Jarsjö ${ }^{1}$, K. Brugger ${ }^{2}$, P. Jansson ${ }^{1}$, and G. Rosqvist ${ }^{1}$ \\ ${ }^{1}$ Department of Physical Geography, Stockholm University, 10691 Stockholm, Sweden \\ ${ }^{2}$ Geology Discipline, University of Minnesota-Morris, Morris, MN 56267, USA \\ Correspondence to: C. C. Clason (caroline.clason@natgeo.su.se)
}

Received: 5 November 2014 - Published in Hydrol. Earth Syst. Sci. Discuss.: 15 December 2014

Revised: 6 May 2015 - Accepted: 18 May 2015 - Published: 15 June 2015

\begin{abstract}
Over $11000 \mathrm{~L}$ of kerosene was deposited on the surface of Rabots glaciär on the Kebnekaise Massif, northern Sweden, following the crash of a Royal Norwegian Air Force aircraft in March 2012. An environmental monitoring programme was subsequently commissioned, including a series of dye tracing experiments during the 2013 melt season, conducted to investigate the transport of pollutants through the glacier hydrological system. This experimental set-up provided a basis from which we could gain new insight into the internal hydrological system of Rabots glaciär. Results of dye tracing experiments reveal a degree of homogeneity in the topology of the drainage system throughout July and August, with an increase in efficiency as the season progresses, as reflected by decreasing temporary storage and dispersivity. Early onset of melting likely led to formation of an efficient, discrete drainage system early in the melt season, subject to decreasing sinuosity and braiding as the season progressed. Four distinct meltwater flow regimes are identified to summarize the temporal and spatial evolution of the system. Analysis of turbidity-discharge hysteresis further supports the formation of discrete, efficient drainage, with clockwise diurnal hysteresis suggesting easy mobilization of readily available sediments in channels. Dye injection immediately downstream of the pollution source zone reveals prolonged storage of dye followed by fast, efficient release. Twinned with a low dye recovery, and supported by sporadic detection of hydrocarbons in the proglacial river, we suggest that meltwater, and thus pollutants in solution, may be released periodically through an efficient, and likely pressurized, hydrological system within the upper reaches of the glacier.
\end{abstract}

\section{Introduction}

Dye tracing provides an opportunity to study the otherwise unseen drainage system inside and underneath glaciers. Measuring the rapidity and pattern of dye emergence, as well as the quantity of dye recovered at the proglacial outlet, can provide important insight into the form and efficiency of the glacier drainage system (e.g. Nienow et al., 1998; Willis et al., 2009; Cowton et al., 2013). Dye tracing has been applied successfully in the alpine environment in several studies and has contributed substantially to understanding of subglacial drainage systems, for example, Storglaciären in the Kebnekaise mountains in northern Sweden (e.g. Seaberg et al., 1988; Hock and Hooke, 1993), glaciers in the European Alps (e.g. Nienow et al., 1998), the High Artic (e.g. Bingham et al., 2005) and, more recently, the Greenland Ice Sheet (Chandler et al., 2013; Cowton et al., 2013). More generally, the number of extensive dye tracer studies of glaciers is still limited (Willis et al., 2012), and basic unresolved issues remain in understanding the temporal and spatial variability of glacial drainage systems, the extent of efficient drainage, and the morphology of englacial and subglacial drainage.

Rabots glaciär considered here in the Kebnekaise mountains was subject to a large spill of hydrocarbons, originating from a crash of a Royal Norwegian Air Force Lockheed Martin C-130J Super Hercules aircraft on 15 March 2012. The aircraft crashed into the western face of Kebnekaise, approximately $50 \mathrm{~m}$ below the mountain ridge, during a military exercise. Of the initial $14100 \mathrm{~L}$ of kerosene jet fuel on board at take-off, an estimated minimum of $11100 \mathrm{~L}$ was sprayed over the snow and ice-covered mountain environment, together with $50 \mathrm{~L}$ of hydraulic oil and $170 \mathrm{~L}$ of turbo 


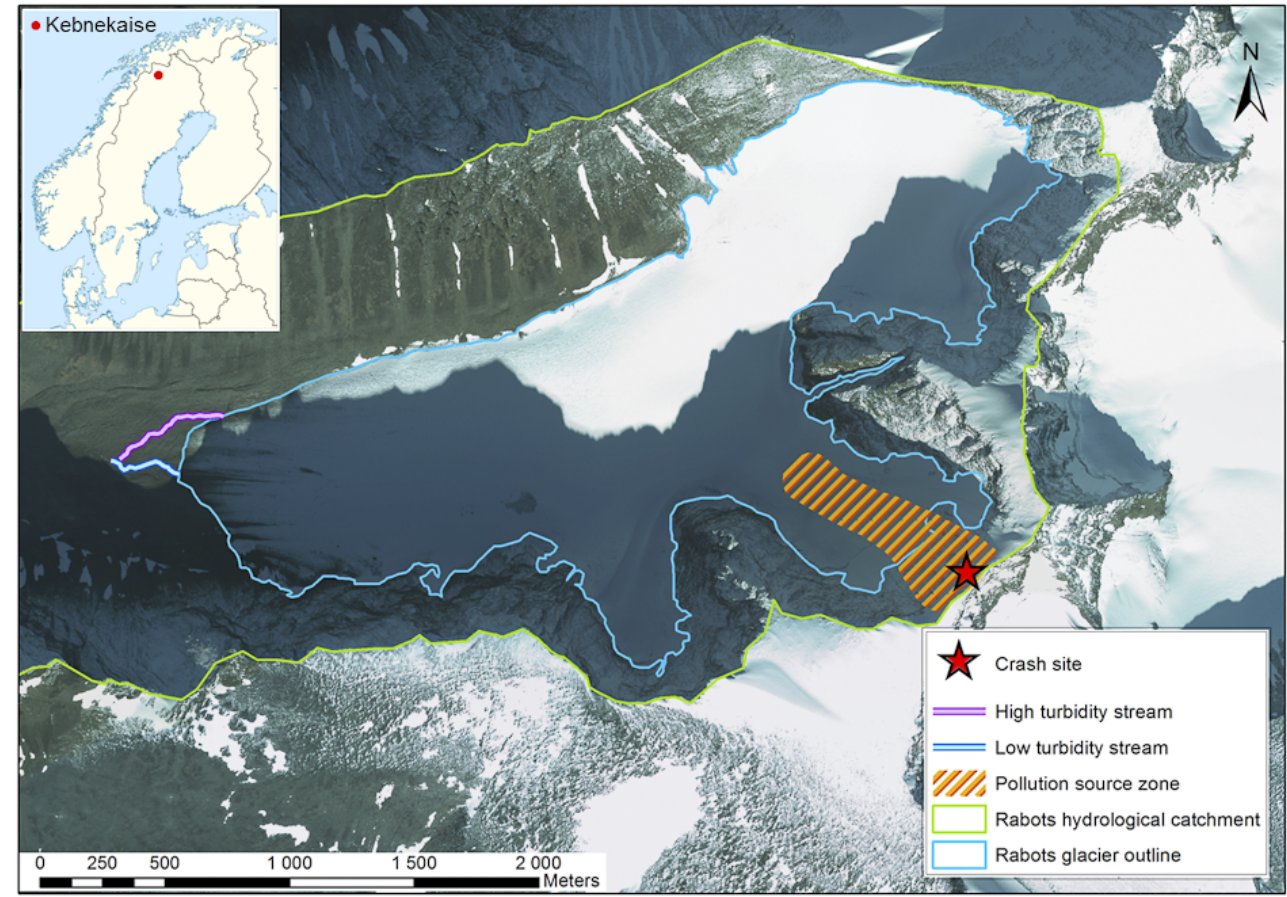

Figure 1. Rabots glaciär with glacier extent marked in blue and the hydrological catchment in green. The site of the plane impact is depicted by the red star, and the orange spotted area represents the estimated area of the initial source zone of hydrocarbon pollutants. The background image is an orthophoto captured in 2008 by Lantmäteriet.

oil (Rosqvist et al., 2014). Some of the kerosene was subsequently swept down and buried on Rabots glaciär by a large snow avalanche along with the wreckage. Wreckage debris was also found on neighbouring Storglaciären and Björlings glacier, but the majority was deposited on Rabots glaciär, which was not subject to immediate clean-up or decontamination of fuel due to the hazardous nature of the impact site and the large volume of snow affected.

Hydrocarbons were detected in the snow pack of the pollution source zone on Rabots glaciär (Fig. 1) and at sporadic intervals in the proglacial river system during the 2013 melt season (Rosqvist et al., 2014). This provides evidence for active advection of pollutants through the glacier system during 2013, the properties of which are discussed here following the application of dye tracing. The transport of hydrocarbon pollution through a full glacier system has never been studied before, and thus dye tracing is imperative if we are to understand anything about advective travel times of pollutants in a glacier system.

Here, we present the results of dye tracing experiments conducted as part of a monitoring programme on Rabots glaciär during the 2013 melt season, commissioned by the National Property Board of Sweden (Statens Fastighetsverk). The main objectives are (i) to provide new temporal and spatial information on the previously little-studied hydrological system of Rabots glaciär, (ii) to identify distinct meltwater flow regimes within the glacial hydrological system based on analytically derived properties of dye returns and (iii) to apply dye breakthrough characteristics to evaluation of the transport of hydrocarbon pollution from the source zone to the proglacial environment.

Rabots glaciär has received relatively little attention compared to neighbouring Storglaciären, which is the best studied glacier in Sweden (e.g. Stenborg, 1965, 1969, 1973; Nilsson and Sundblad, 1975; Schytt, 1981; Holmlund, 1988; Jansson, 1996; Schneider, 1999; Glasser et al., 2003, Fountain et al., 2005), and an understanding of its hydrological system has been extremely limited until now. The majority of dye tracing experiments in moulins on Storglaciären have been conducted in the lower ablation zone below a riegel in the bedrock topography (e.g. Seaberg et al., 1988; Hock and Hooke, 1993; Kohler, 1995), as the overdeepened trough upstream of the riegel results in a largely englacial drainage system (Hooke et al., 1988; Pohjola, 1994; Fountain et al., 2005) and an absence of surface meltwater input points. Dye tracing experiments conducted in crevasses, moulins or boreholes at elevations above the riegel on Storglaciären have thus been limited and produced very attenuated, or, in some cases, no dye return (Hooke et al., 1988; Jansson, 1996). The greater variability in subglacial topography beneath Storglaciären, compared to Rabots glacär (Björnsson, 1981) results in differences in surface to bed connections. On storglaciären input points are highly localized to the riegel area, whereas on Rabots glacär points are scattered across a large portion of 
the glacier surface. To evaluate pollution transport through Rabots glaciär it is thus clear that the knowledge from Storglaciären is not sufficient or even applicable. The results presented below thus provide new insights into the hydrology of Rabots glaciär with the aim of providing a basis for monitoring pollution transport. The study also highlights the contrasts between the two glaciers and the effect of basal topography on the form and behaviour of the hydrological system.

\section{Site description}

Rabots glaciär is a small, $3.1 \mathrm{~km}^{2}$, polythermal valley glacier, situated on the western side of Kebnekaise ( 2099 m a.s.l.) in sub-Arctic Sweden (Fig. 1). The glacier extends from $1848 \mathrm{~m}$ a.s.l. at its highest point down to $1111 \mathrm{~m}$ a.s.l. at the snout, with an average slope of $11.5^{\circ}$. The maximum recorded Little Ice Age (LIA) extent of Rabots glaciär dates to 1910, as captured in photographs taken in 1910 by Enqvist (Brugger and Pankratz, 2014). In comparison to neighbouring Storglaciären, which has been characterized by a relatively stable terminus position in the last ca. 20 years, significant retreat of Rabots glaciär from its LIA maximum and thinning continues due to its longer response time to climatic changes (Brugger, 2007). Radio-echo sounding conducted in 1979 found that Rabots glaciär had a maximum ice thickness of $175 \mathrm{~m}$, with an average of $84 \mathrm{~m}$ (Björnsson, 1981). It also revealed that the subglacial topography underneath Rabots glaciär is gently sloping with no pronounced overdeepenings. This is in contrast to Storglaciären, for which the bed is characterized by several subglacial overdeepenings and a pronounced bedrock riegel (Björnsson, 1981). One may then expect Rabots glaciär to exhibit different hydrological behaviour due to the less complex nature of topography beneath the glacier. Meltwater at the terminus of Rabots glaciär leaves primarily through two proglacial streams. The high turbidity of the northernmost of these streams indicates that it has much more interaction with bed sediments than its relatively clear southern counterpart. The proglacial environment is characterized by several braided systems that travel through an overridden inner moraine and a pronounced terminal moraine (Karlén, 1973). The overall hydrological catchment size amounts to $9 \mathrm{~km}^{2}$, with an ice-covered area of $33 \%$.

\section{Methods}

\subsection{Meteorological data}

Meteorological data were recorded between April and September 2013 by an automatic weather station at 1355 m a.s.l. on Rabots glaciär. Meteorological variables, including air temperature and precipitation, were measured every minute and the mean of these measurements stored at 15 min intervals. Air temperature was measured at $0.5,1$ and
$2 \mathrm{~m}$ above the surface using HygroClip T/Rh sensors and recorded as both transient and average values. Total precipitation was recorded by a Young unheated tipping bucket rain gauge.

\subsection{Proglacial river discharge}

River gauging was conducted at a stable bedrock location in the proglacial river during the 2013 melt season, ca. $1.5 \mathrm{~km}$ downstream of the glacier terminus (Fig. 2). This location permitted convergence of the proglacial outlets and measurement in an area of constrained flow downstream of the numerous braided systems operating between terminal moraines. Measurements of river stage and of air and water pressure were conducted between days 203 and 248 (Fig. 3). Stage was measured by a SR50A sonic ranging sensor and pressure was recorded by HOBO U20 data loggers. Discharge time series were constructed from both relative gauging height (every $15 \mathrm{~min}$ ) and relative water pressure (every $10 \mathrm{~min}$ ) based on a rating curve produced by relating measured stage and pressure to discharge calculated for repeated Rhodamine dye tracings (D1 to D5; Table 1) representative of varying water levels in the proglacial river.

\subsection{Dye tracing experiments}

Field campaigns targeting glacial hydrology were conducted during July and August 2013, during which 15 dye tracing experiments were carried out to quantify transit times and properties of meltwater flow through crevasses in the upper reaches of the glacier, moulins throughout the ablation zone (Fig. 2), and in the proglacial river (Table 1). Experiments were conducted across the altitudinal range of flowing surface meltwater on the glacier in order to understand how the englacial and subglacial hydrological system changes with elevation and distance from the terminus. Dye injections in the pollution source zone alone provide only an average of englacial/subglacial conditions across the full altitudinal extent of the ablation zone. A known quantity of Rhodamine water tracer (RWT) $20 \%$ solution was used in the majority of dye tracer experiments, with Uranine (Na Fluorescein) $33.3 \%$ solution used when simultaneous experiments were possible. Uranine is susceptible to photo-degradation, so injection was conducted as close as safely possible to the englacial opening to reduce time exposed to sunlight. Dye was injected into flowing water in every case, upstream of open crevasses and moulins. Emergence of the dye was measured using both manual sampling and automated detection methods, and for all experiments the sampling rates for both automatic and manual detection were less than $1 / 16$ of the measured residence time (the time between dye injection and maximum detected concentration), as suggested by Nienow et al. (1996) to be the maximum acceptable period for accurate estimation of dispersivity. 


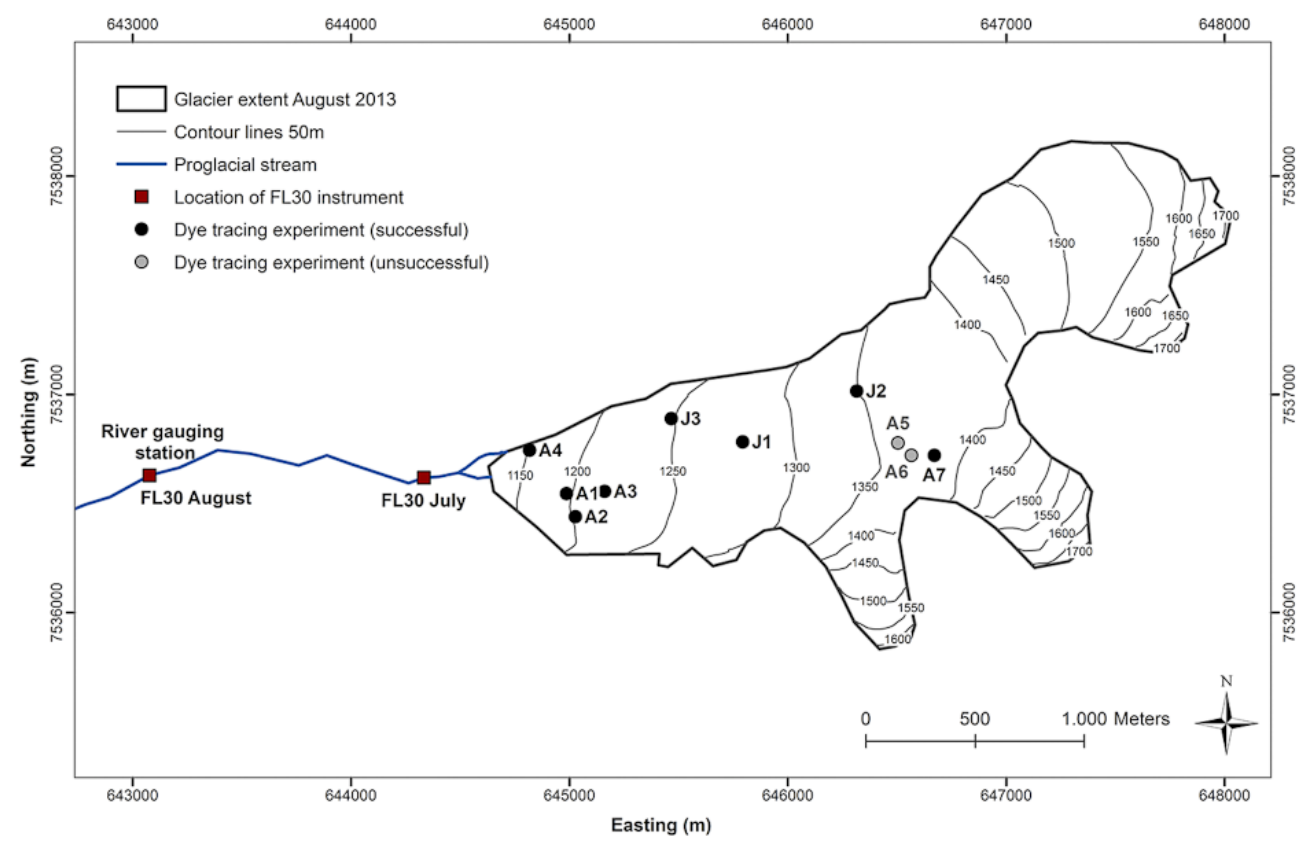

Figure 2. Locations of glacier-based dye tracing experiments during 2013.

Table 1. Dye tracing experiments conducted on Rabots glaciär and in the proglacial river during 2013. J denotes July, A denotes August and D represents proglacial experiments.

\begin{tabular}{lrllrlr}
\hline Code & $\begin{array}{r}\text { Day of year, } \\
\text { injection time }\end{array}$ & Injection site & Tracer & $\begin{array}{r}\text { Amount } \\
(\mathrm{mL})\end{array}$ & Sampling (rate in min) & $\begin{array}{r}\text { Dye } \\
\text { return }\end{array}$ \\
\hline J1 & $185,14: 47$ & Supraglacial stream & RWT & 125 & Auto (0.03); manual (10) & Yes \\
J2 & $186,11: 37$ & Crevasse & RWT & 245 & Auto (0.03); manual (10) & Yes \\
J3 & $203,12: 00$ & Moulin & RWT & 250 & Auto (0.03); manual (10) & Yes \\
A1 & $220,16: 33$ & Moulin & RWT & 150 & Auto (0.5) & Yes \\
A2 & $220,16: 46$ & Moulin & Uranine & 100 & Auto (0.5) & Yes \\
A3 & $221,14: 27$ & Moulin & RWT & 150 & Auto (0.5) & Yes \\
A4 & $221,15: 26$ & Moulin & Uranine & 100 & Auto (0.5) & Yes \\
A5 & $222,13: 33$ & Crevasse & Uranine & 200 & Auto (0.5) & No \\
A6 & $222,15: 10$ & Supraglacial stream & RWT & 125 & Auto (0.5) & No \\
A7 & $227,13: 16$ & Supraglacial stream & RWT & 500 & Auto (0.5); manual (10) & Yes \\
D1 & $220,12: 40$ & River & RWT & 30 & Auto (0.5) & Yes \\
D2 & $222,10: 49$ & River & RWT & 30 & Auto (0.5) & Yes \\
D3 & $227,12: 37$ & River & RWT & 60 & Auto (0.5) & Yes \\
D4 & $230,12: 22$ & River & RWT & 50 & Auto (0.5) & Yes \\
D5 & $230,13: 26$ & River & RWT & 100 & Auto (0.5) & Yes \\
\hline
\end{tabular}

For automated detection of dye emergence, an Albillia GGUN-FL30 field fluorometer was stationed in the proglacial stream (Figs. 1 and 2), and was monitored at regular intervals to check the stability of the sonde within the stream. The FL30 is a flow-through fluorometer with a minimum detection limit of ca. $2 \times 10^{-11} \mathrm{~g} \mathrm{~mL}^{-1}$, and allows detection of three separate tracers simultaneously, in addition to measuring turbidity and water temperature, at a sampling rate of up to $2 \mathrm{~s}$. In order to establish the preferential flow pathway for meltwater originating at the hydrocarbon source zone, water samples were taken manually in both of the main streams emerging from the glacier front (Figs. 1 and 2) during experiment A7. The samples were analysed for fluorescence with a Turner Designs AquaFluor handheld fluorometer, set up for RWT at a minimum detection limit of $0.4 \mathrm{ppb}$. Based on calibration of the instruments (for a $100 \mathrm{ppb}$ solution), fluorescence was converted to dye return concentration to produce breakthrough curves for each experiment. These dye returns were subsequently used to calculate the throughflow velocity, dispersion coefficient, dispersivity, storage re- 
Table 2. Results of dye tracing analysis from automatic sampling of fluorescence (A7* is based on manual sampling in the southernmost proglacial outlet). Here, discharge for $\mathrm{A}$ and $\mathrm{J}$ experiments is that calculated from stage recorded at the river gauging station averaged over the duration of each experiment, and for $\mathrm{D}$ experiments is the computed discharge based on dye tracing for production of the rating curve.

\begin{tabular}{|c|c|c|c|c|c|c|c|c|}
\hline Code & $\begin{array}{l}\text { Day of year, } \\
\text { injection time }\end{array}$ & $\begin{array}{r}\text { Transit } \\
\text { distance } \\
(\mathrm{m})\end{array}$ & $\begin{array}{r}\text { Throughflow } \\
\text { velocity } \\
\left(\mathrm{m} \mathrm{s}^{-1}\right)\end{array}$ & $\begin{array}{c}\text { Dispersion } \\
\text { coefficient } \\
\left(\mathrm{m}^{2} \mathrm{~s}^{-1}\right)\end{array}$ & $\begin{array}{r}\text { Dispersivity } \\
(\mathrm{m})\end{array}$ & $\begin{array}{r}\text { Storage } \\
\text { retardation } \\
(\%)\end{array}$ & $\begin{array}{r}\text { Dye } \\
\text { recovery } \\
(\%)\end{array}$ & $\begin{array}{c}\text { Discharge } \\
\left(\mathrm{m}^{3} \mathrm{~s}^{-1}\right)\end{array}$ \\
\hline $\mathrm{J} 1$ & $185,14: 47$ & 1469 & 0.28 & 24.27 & 86.24 & 70.82 & $\mathrm{n} / \mathrm{a}$ & $\mathrm{n} / \mathrm{a}$ \\
\hline $\mathrm{J} 2$ & $186,11: 37$ & 2022 & 0.21 & 19.33 & 92.63 & 58.51 & $\mathrm{n} / \mathrm{a}$ & $\mathrm{n} / \mathrm{a}$ \\
\hline $\mathrm{J} 3$ & $203,12: 00$ & 1165 & 0.15 & 4.04 & 27.79 & 43.86 & $\mathrm{n} / \mathrm{a}$ & $\mathrm{n} / \mathrm{a}$ \\
\hline A1 & $220,16: 33$ & 655 & 0.25 & 2.84 & 11.59 & 10.71 & 70.70 & 2.01 \\
\hline $\mathrm{A} 2$ & $220,16: 46$ & 703 & 0.19 & 0.81 & 4.25 & 13.84 & 18.79 & 2.00 \\
\hline A3 & $221,14: 27$ & 829 & 0.06 & 0.19 & 2.89 & 10.78 & 78.69 & 1.61 \\
\hline A4 & $221,15: 26$ & 488 & 0.23 & 1.22 & 5.34 & 11.03 & 8.77 & 1.60 \\
\hline A7 & $227,13: 16$ & 2339 & 0.04 & 0.79 & 18.01 & 5.03 & 8.25 & 1.28 \\
\hline $\mathrm{A} 7^{*}$ & $227,13: 16$ & 2182 & 0.04 & 1.10 & 28.78 & 58.56 & 23.70 & 1.28 \\
\hline D1 & $220,12: 40$ & 685 & 0.38 & 0.59 & 1.56 & 38.5 & 55.05 & 1.73 \\
\hline D2 & $222,10: 49$ & 874 & 0.23 & 1.46 & 6.43 & 20.64 & 81.50 & 1.08 \\
\hline D3 & $227,12: 37$ & 1237 & 0.36 & 2.91 & 8.11 & 24.77 & 93.52 & 1.28 \\
\hline D4 & $230,12: 22$ & 408 & 0.24 & 0.10 & 0.41 & 17.80 & 77.69 & 2.36 \\
\hline D5 & $230,13: 26$ & 1534 & 0.58 & 4.11 & 7.08 & 31.31 & 89.18 & 2.20 \\
\hline
\end{tabular}

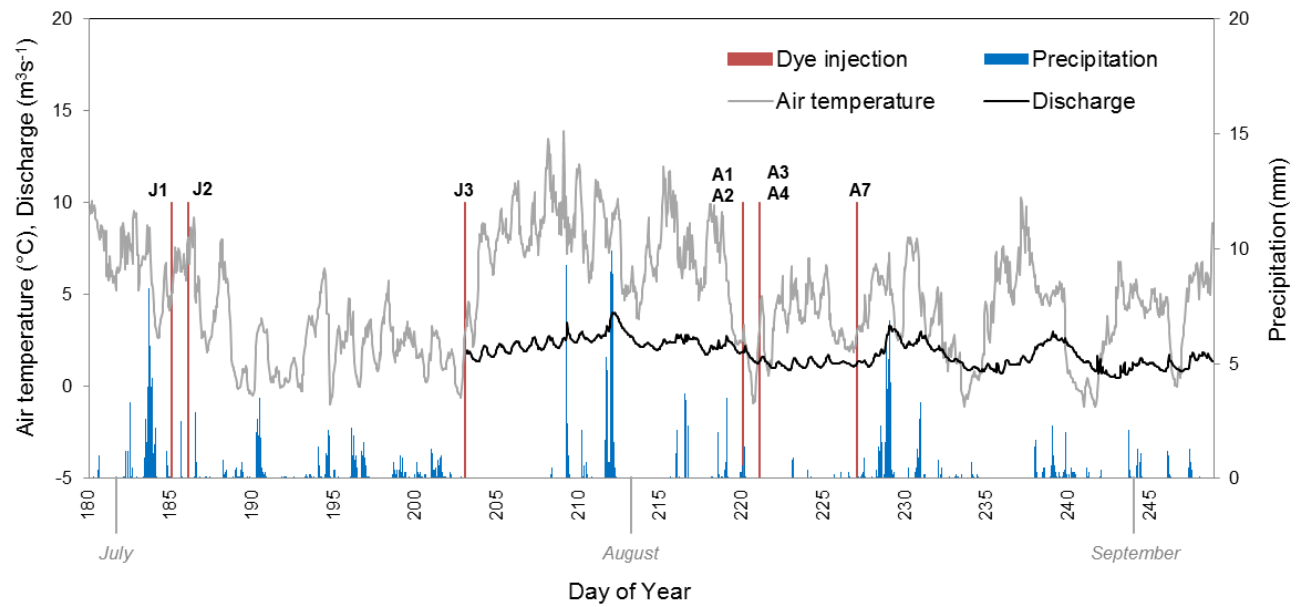

Figure 3. Measured $2 \mathrm{~m}$ air temperature, precipitation and proglacial discharge (calculated from relative gauging height) during summer 2013 (data illustrated span 29 June-5 September). Values are plotted at hourly intervals where temperature and discharge are averages, and precipitation is a total. The timing of successful glacier-based dye injections is indicated in red.

tardation and dye recovery for each successful experiment (Table 2).

\subsection{Dye breakthrough analysis}

For each dye return a modelled concentration-time (breakthrough) curve was calculated using an advection-dispersion model (Brugman, unpublished data; Seaberg et al., 1988; Cowton et al., 2013), at a temporal resolution of $30 \mathrm{~s}$. The concentration of dye is represented as $c$ at time $t$, where $V_{0}$ represents the volume of injected dye, and $Q$ is discharge $\left(\mathrm{m}^{3} \mathrm{~s}^{-1}\right)$, which was allowed to vary freely in order to produce a best fit to the measured breakthrough curve for each experiment (Willis et al., 1990; 2009). Variation of $Q$ was permitted even for the August experiments where $Q$ was measured, since discharge does not remain constant throughout an experiment, and to account for error associated with deriving discharge from a rating curve:

$c(t)=\frac{v}{Q} \frac{V_{0}}{\sqrt{(4 \pi D t)}} \exp -\frac{(x-v t)^{2}}{4 D t}$.

Throughflow velocity, or transit speed, $v\left(\mathrm{~m} \mathrm{~s}^{-1}\right)$, for each experiment is calculated as

$v=\frac{x}{t_{\mathrm{m}}}$ 
where the transit distance $x(\mathrm{~m})$ is the straight line distance between the injection point and sampling location, and the residence time $t_{\mathrm{m}}(\mathrm{s})$ is the time between dye injection and peak concentration. This value was corrected for travel time in the stream during the August experiments to account for the different positioning of the FL30 fluorometer in July and August. The dispersion coefficient $D\left(\mathrm{~m}^{2} \mathrm{~s}^{-1}\right)$ in Eq. (1) indicates the rate at which dye spreads within the glacier hydrological system (Willis et al., 2009). The variable $t_{j}$ represents the time taken until half of the peak concentration on the rising $\left(t_{j}=t_{1}\right)$ and falling $\left(t_{j}=t_{2}\right)$ limbs of the measured dye return curve. The equation is solved iteratively for $t_{\mathrm{m}}$ for both $t_{j}=t_{1}$ and $t_{j}=t_{2}$ until the equations converge to obtain the same value of $D$ (Seaberg et al., 1988):

$$
D=\frac{x^{2}\left(t_{\mathrm{m}}-t_{j}\right)^{2}}{4 t_{\mathrm{m}}^{2} t_{j} \ln \left(2 \sqrt{\frac{t_{\mathrm{m}}}{t_{j}}}\right)} .
$$

Dispersivity, $d(\mathrm{~m})$, is further calculated to describe the spreading rate of dye relative to the transit velocity through the glacier, providing an inference for transit route complexity (Seaberg et al., 1988; Willis et al., 1990):

$d=\frac{D}{v}$.

Temporary storage of dye in the glacier results in elongation of the falling limb of the modelled return curve, and is not accounted for in the advection-dispersion model (Seaberg et al., 1988; Schuler et al., 2004; Willis et al., 2009). To examine this, storage retardation, SR, is thus quantified as the percentage area difference under the measured and modelled falling limbs (Nienow, 1993; Schuler, 2002; Cowton et al., 2013). The higher the SR, the lower the fit between the modelled and measured curves, thus the higher the temporary storage. Furthermore, dye recovery, $W(\mathrm{~g})$, describes the weight of dye which passed through the fluorometer during an experiment, where $\mathrm{d} t$ is the logger interval in seconds, and $Q$ is the average measured discharge for the duration of the experiment:

$W=\sum_{t=1}^{n} c Q \mathrm{~d} t$

The percentage dye recovery can then be expressed as a percentage, $W \%$, where $W_{0}$ is the initial mass of the injected tracer:

$W \%=100 \frac{W}{W_{0}}$.

\section{Results and interpretation}

\subsection{Proglacial discharge}

Discharge in the proglacial river remains relatively small throughout the measurement period, with an average of
$1.8 \mathrm{~m}^{3} \mathrm{~s}^{-1}$. In response to relatively high air temperatures in July (Fig. 3), discharge reaches a maximum of $3.9 \mathrm{~m}^{3} \mathrm{~s}^{-1}$ on day 212, before experiencing a step-wise decrease to a period of steady discharge averaging around ca. $1.3 \mathrm{~m}^{3} \mathrm{~s}^{-1}$ from day 221 to day 227. The second half of August is characterized by discharge fluctuating by ca. $2 \mathrm{~m}^{3} \mathrm{~s}^{-1}$ in response to rainfall events and periods of higher air temperatures. Average discharge continues to fall into September. The diurnal cycle of discharge lags that of air temperature, with peak discharge occurring daily on average ca. $2 \mathrm{~h}$ after peak recorded air temperature, representing the response time of the river to ablation and transit of meltwater through the glacier. The amplitude of the diurnal discharge cycle decreases throughout the melt season (Fig. 3).

\subsection{Turbidity}

The turbidity of the proglacial river system, recorded in nephelometric turbidity units (NTU), was not measured continuously throughout the season, but was measured contemporaneously with dye fluorescence at the river gauging station (Fig. 2) during 6 out of 10 days in August 2013. Average peak discharge occurs within $1 \mathrm{~h}$ of average peak turbidity (Fig. 4c), indicating that mobilization of sediments leads discharge. Hysteresis, a behaviour for which a value of the dependent variable can vary for a given value of the independent variable, depending on whether the independent variable is increasing or decreasing (Hodgkins, 1996), is observed both at the diurnal scale and on a multi-day scale, over a period of 10 days (Fig. 4a and b). On the diurnal scale, hysteresis was observed only in a clockwise direction, while a figure-eight was produced on the multi-day scale, encompassing both clockwise and anticlockwise behaviour (Fig. 4a, b). Clockwise hysteresis implies that peak diurnal turbidity leads peak diurnal discharge, as exemplified in Fig. 4c, such that for equivalent discharge values on the rising and falling limbs of the hydrograph, turbidity is higher on the rising than the falling limb (Hodgkins, 1996). In this context, clockwise hysteresis can be interpreted as easy mobilization of fresh sediment flushed out from channel beds and margins, followed by an exhaustion of sediment supply (Hodgkins, 1996; Singh et al., 2005; Pietrón et al., 2015). Given the short period of time over which turbidity was recorded at Rabots glaciär, it is not possible to investigate multi-day evolution of sediment mobilization over the melt season. However, within a limited period of 10 days, we observe a figure-eight clockwise/anticlockwise hysteresis loop (Fig. 4b). Conversely to clockwise behaviour, anticlockwise hysteresis implies that the peak in diurnal discharge leads the peak in diurnal turbidity, indicating that sediments are not as easily mobilized.

Diurnal observations of hysteresis in the proglacial river of Rabots glaciär were entirely clockwise, and are therefore comparable with the largely clockwise hysteresis recorded by Singh et al. (2005) for Gangotri Glacier in the Himalayas. Data collection in the Gangotri study, however, 

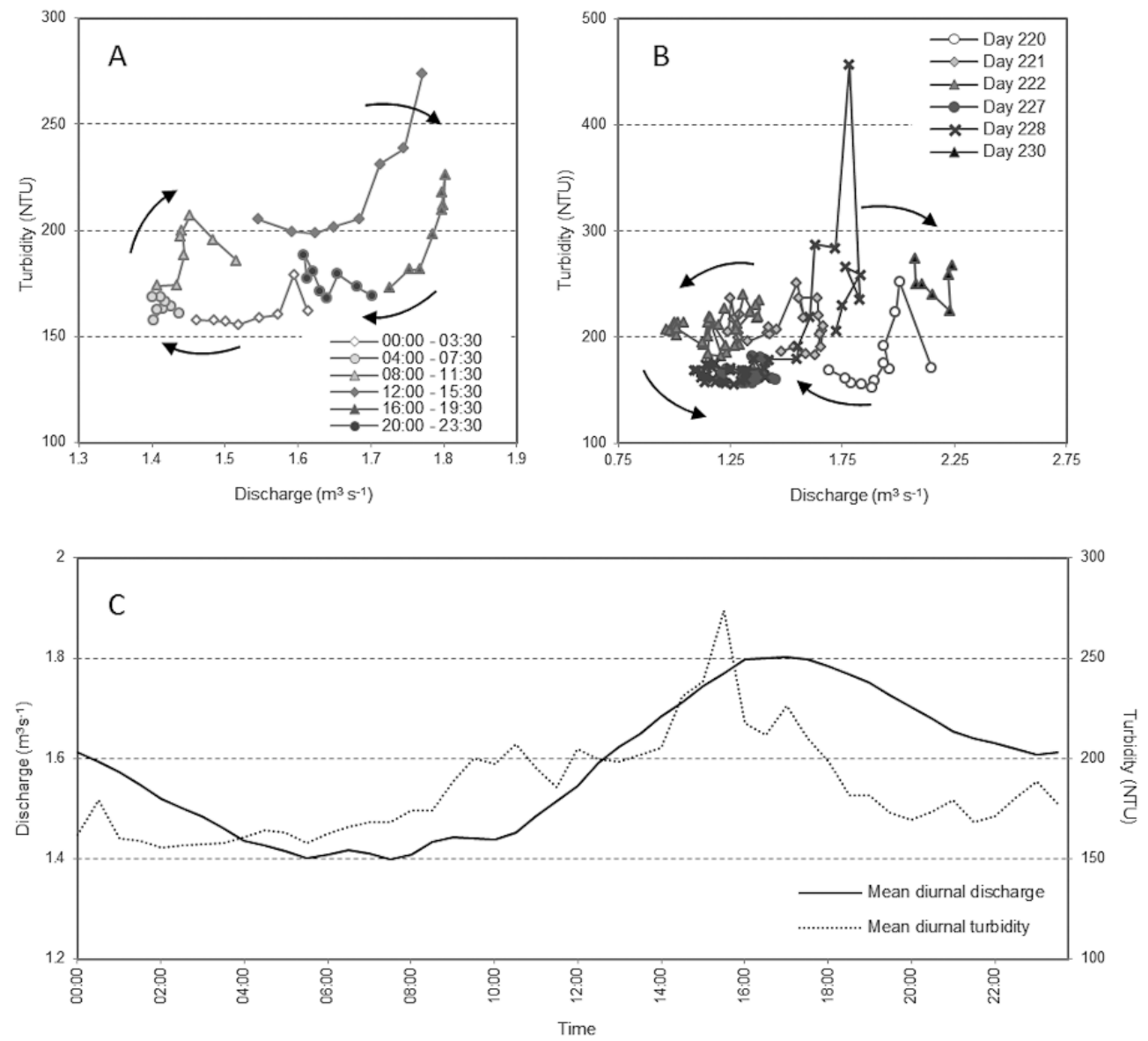

Figure 4. (a) Diurnal turbidity, averaged at 30 min intervals across all measurement days, plotted against mean diurnal discharge, (b) all available measurements of turbidity (30 min intervals) plotted against discharge, and (c) diurnal cycle of discharge and turbidity averaged at 30 min intervals for all available measurements between days 220 and 230 .

extended over a full melt season, much longer than our 10 day, non-continuous measurement period. One may compare further with observations of hysteresis at Scott Turnerbreen in Svalbard (Hodgkins, 1996), for which a progressive change in hysteresis from clockwise to anticlockwise was observed during the melt season. Scott Turnerbreen is a "cold-based", non-temperate glacier (Hodgkins, 1996), while Rabots glaciär is polythermal, and because of differences in the glacier hydrological system, particularly at the bed, this may explain why we do not see anticlockwise diurnal hysteresis in the late melt season at Rabots glaciär. Temperate Bench Glacier in Alaska has also been observed to produce clockwise behaviour, including during two flood events (Riihimaki et al., 2005). The anticlockwise pattern observed between days 220 and 222 (Fi. 4b) follows a period of increased temperatures between days 217 and 219 (Fig. 3). Sediments within the glacier system may have been flushed out and sourced from higher elevation during this period due to higher melt rates, followed by a period of sediment exhaustion. This may have been exacerbated by the prevalence of silty sediments subject to strong cohesion in the glacier forefield, reducing the possibility of sediment mobilization. The sharp increase in turbidity in the Rabots glaciär proglacial stream during day 228 is likely a reflection of a peak in temperature, combined with a precipitation event, lagged by a peak in discharge (Fig. 3). We hypothesize that increased temperature, and thus increased meltwater availability, combined with a precipitation event (Fig. 3), may have permitted extension of the network of subglacial conduits during this period, allowing access to a fresh sediment supply at the glacier bed, as also observed by Riihimaki et al. (2005).

\subsection{Dye breakthrough}

Results from calculation of analytical dye return parameters for each experiment are listed in Table 2, along with discharge calculated for each experiment based on measurements in the proglacial river. Measured and modelled breakthrough curves are illustrated for each successful glacier dye tracing experiment in Fig. 5. Experiments A5 and A6 were unsuccessful due to failure of the fluorometer data logger. 

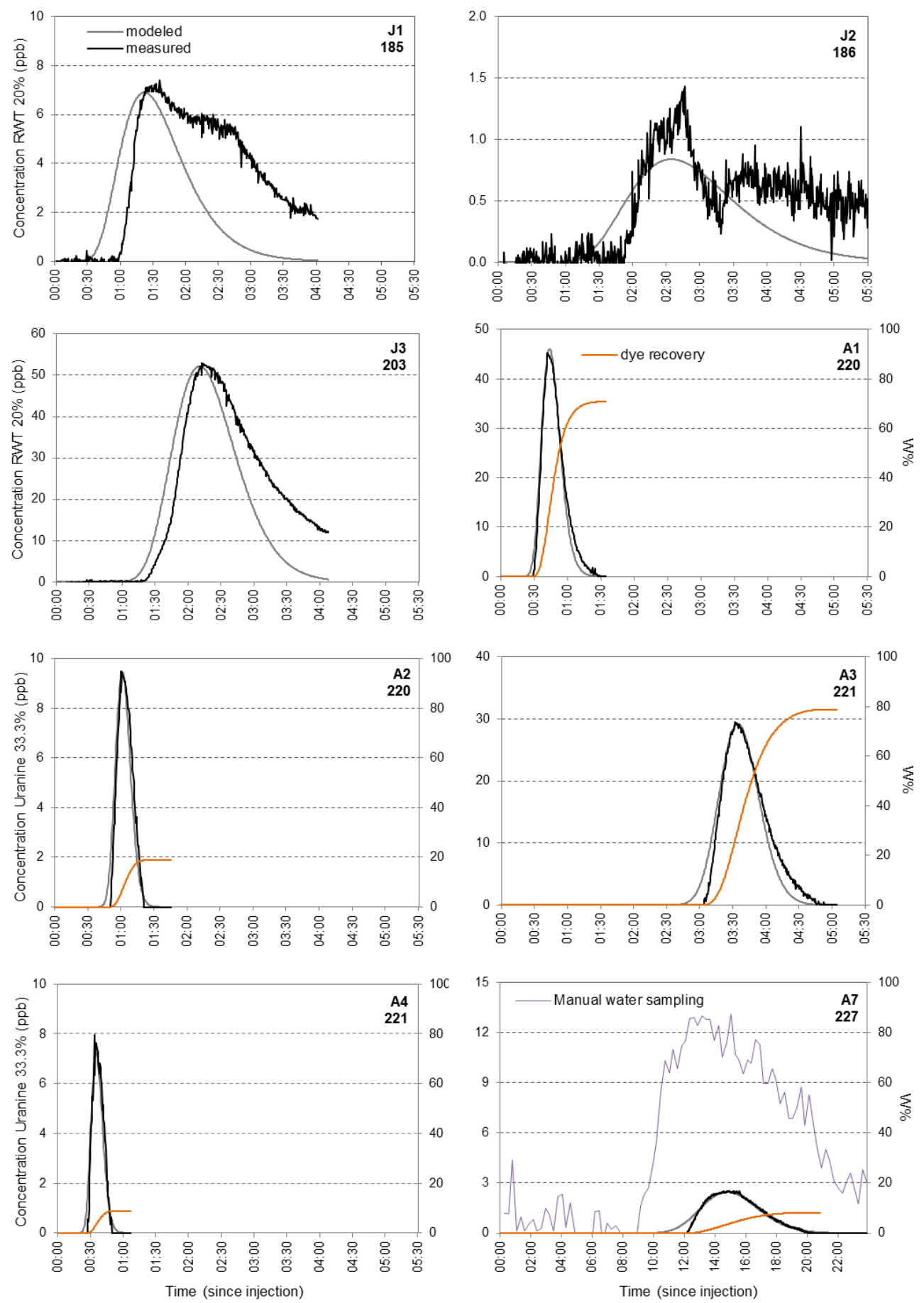

Figure 5. Modelled and measured dye breakthrough curves, including dye recovery for the August experiments. Discharge was not measured during the course of the July experiments, preventing the calculation of dye recovery. Note that the $x$ axis for experiment A7 differs from the others due to the particularly long dye return time, and the $y$ axes are scaled differently for each experiment in order to best illustrate the form of the breakthrough curves.

Dye recovery is included for the August experiments only since discharge, from which dye recovery is calculated, was not measured during the July experiments. Visual interpretations of the breakthrough curves reveal that there is a de- crease in curve width with progression of the season, as well as an increase in symmetry. All curves except $\mathbf{J} 1$ and $\mathbf{J} 2$ exhibit a smooth asymmetric form, as observed elsewhere (e.g. Seaberg et al., 1988; Willis et al., 1990; Cowton et 
al., 2013), and are characterized by clear single-peak breakthrough curves. Breakthrough curves J1 and J2 are more complex in form, with longer falling limbs that do not reach base level values before the end of the experiment period. These curves are also characterized by a higher degree of noise, which may be attributed to low dye recovery, interaction with basal sediments, and/or complex flow pathways. Breakthrough curves characterized by rapid dye return, with a narrow, single-peaked form, are interpreted to be indicative of an efficient subglacial/englacial drainage system (Hubbard and Nienow, 1997). This interpretation is further strengthened by low values of dispersivity and storage, and fast throughflow velocities, indicative of high throughput of water in a channelized system (e.g. Cowton et al., 2013).

Experiment A7 was monitored simultaneously by both automated fluorescence detection and manual water sampling in both major proglacial outlets. Manual sampling revealed dye emergence in only the southernmost, less turbid proglacial outlet. The dye breakthrough curve derived from the analysis of water from manual sampling was in accordance with that from automated detection in terms of the general breakthrough curve form and the time of peak concentration, but was characterized by much-increased noise and increased dye concentration. This is likely due to turbidity, which is not corrected for in manual sampling, causing increased scattering of light resulting in unrepresentatively high concentration readings. Imperfections in the sampling bottles and cuvettes used to analyse manual water samples can also introduce error into measured dye concentrations. The breakthrough curves of experiment A7 represent meltwater flow from as close to the pollution source zone as was possible with the prerequisite of flowing water for dye injection. Both curves reached their peak ca. $14 \mathrm{~h}$ after injection, after ca. $12 \mathrm{~h}$ with no dye signal (in the case of automated detection). The residence time, form of the breakthrough curves and emergence of dye in only the less turbid proglacial outlet indicates temporary storage followed by a rapid release of meltwater, with limited interaction with sediments at the bed.

\subsection{Throughflow velocities}

Calculated throughflow velocities are an average of flow velocities within the englacial and subglacial drainage system between the injection site and detection point. Throughflow velocities range from 0.04 to $0.28 \mathrm{~m} \mathrm{~s}^{-1}$ for the glacier-based experiments (Table 2), which fall within the range of values previously inferred from experiments on Storglaciären (Seaberg et al., 1988; Hock and Hooke, 1993). A threshold of $0.2 \mathrm{~m} \mathrm{~s}^{-1}$ is proposed by Theakstone and Knudsen (1981) and Nienow (2011) to distinguish between fast and slow flow. Willis et al. (2009) propose a similar threshold for fast flow, considering velocities of $<0.05 \mathrm{~m} \mathrm{~s}^{-1}$ as slow, ca. $0.1 \mathrm{~m} \mathrm{~s}^{-1}$ as moderate and $>0.15 \mathrm{~m} \mathrm{~s}^{-1}$ as fast. Flow velocities above the proposed thresholds for fast flow have traditionally been interpreted as indicative of channelized transport, while flow velocities below the threshold indicate distributed water routing (Seaberg et al., 1988; Willis et al., 1990; Cowton et al., 2013). Throughflow velocities in Rabots glaciär's proglacial river reached a maximum of $0.58 \mathrm{~m} \mathrm{~s}^{-1}$. We observed no clear relationship between velocity and elevation of dye injections on the glacier, or between velocity and time into the season. The lowest values of throughflow velocity were calculated for experiment A7, and we hypothesize that they are representative of a relatively long period of initial storage before more rapid flow following a sudden release of meltwater.

Following Leopold and Maddock (1954), the relationship between throughflow velocity and discharge can be expressed as a simple power function. There is a positive correlation between throughflow and discharge both for glacierbased dye returns $\left(R^{2}=0.65\right)$ and proglacial returns $\left(R^{2}=\right.$ 0.27 ) at Rabots glaciär (Fig. 6). The results of this study are compared against those from neighbouring polythermal Storglaciären (Seaberg et al., 1988) and temperate outlet glacier Midtdalsbreen, Norway (Willis et al., 1990), in Table 3. Seaberg et al. (1988) differentiated between proglacial and subglacial/englacial flow, while Willis et al. (1990) divided recorded discharge into two tributary systems $\mathrm{T} 1$ and $\mathrm{T} 3$, which were interpreted as draining two different glacial hydrological systems. In the proglacial system of Rabots glaciär, velocity increases with the 0.6 power of the discharge. The associated multiplier is lower than that calculated for Sydjokk, one of the proglacial rivers of neighbouring Storglaciären (Seaberg et al., 1988), such that velocity through Sydjokk is 2.8 times larger than for the Rabots glaciär proglacial river. The braided nature of the Rabots proglacial river as it navigates through the proglacial outwash plain and terminal moraines may explain this difference.

The exponent of the englacial and subglacial drainage is also significantly higher in this study compared with Storglaciären and Midtdalsbreen, while the multiplier is in the same order as that for Midtdalsbreen. For a given discharge, the velocity of water flowing englacially or subglacially or both in Rabots glaciär is thus 2-3 times lower than Midtdalsbreen, and 13 times lower than Storglaciären. The much larger exponent for englacial/subglacial flow through Rabots glaciär may indicate that discharge is accommodated by an increase in hydraulic gradient within the system due to backing up of water, and by decreasing sinuosity, as proposed both for Storglaciären (Seaberg et al., 1988) and T1 of Midtdalsbreen (Willis et al., 1990), rather than through changes in cross-sectional channel area. Cowton et al. (2013) and Nienow et al. (1998) state that a flow in a channelized system is expected to be 1-2 orders of magnitude higher than in a distributed system. We do not see this order of magnitude difference in our data (Table 2), or an increase in velocity over time, which is likely a product of early onset melt and development of the drainage system. 
Table 3. Velocity-discharge analyses from Rabots glaciär, Sweden (this study), Storglaciären, Sweden (Seaberg et al. 1988) and Midtdalsbreen, Norway (Willis et al. 1990). Note that experiments were conducted over a period of 2 years for both Storglaciären and Midtdalsbreen.

\begin{tabular}{llrrrr}
\hline Study & Domain & Sample size & Multiplier & Exponent & $R^{2}$ \\
\hline Clason et al. (this study) & Proglacial & 5 & 0.25 & 0.60 & 0.27 \\
Clason et al. (this study) & Subglacial/englacial & 5 & 0.02 & 3.44 & 0.65 \\
Seaberg et al. (1988) & Proglacial & 13 & 0.69 & 0.27 & $\mathrm{n} / \mathrm{a}$ \\
Seaberg et al. (1988) & Subglacial (Sydjokk) & 6 & 0.26 & 1.00 & $\mathrm{n} / \mathrm{a}$ \\
Willis et al. (1990) & Subglacial/englacial (T1) & 5 & 0.06 & 1.00 & 0.44 \\
Willis et al. (1990) & Subglacial/englacial (T3) & 8 & 0.04 & 0.60 & 0.10 \\
\hline
\end{tabular}

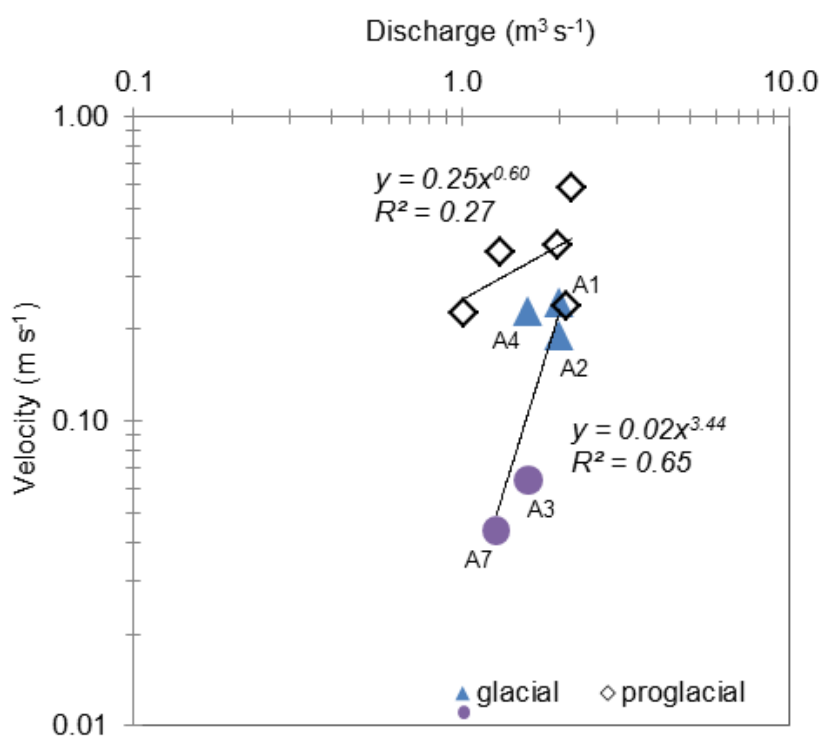

Figure 6. Velocity plotted against discharge for proglacial and glacier-based dye tracer tests conducted during August 2013. Note that the July experiments are not included because there are no contemporaneous measurements of stage from which to calculate discharge. Flow regimes 3 and 4 are illustrated by blue triangles and purple circles respectively.

\subsection{Dispersivity}

Low dispersivities $(<5 \mathrm{~m})$ are typically indicative of efficient water routing, and high values of dispersivity $(>20 \mathrm{~m}$ ) have been associated with drainage of decreased efficiency, possibly due to a distributed drainage system form (Nienow et al., 1998; Bingham et al., 2005; Willis et al., 2009). Water that is stored either supraglacially or englacially may also increase dispersivity (Fountain, 1993; Schuler et al., 2004), for example, through buffering of meltwater flow in snow and firn layers, or storage in englacial fracture networks. From visual interpretation of the return curves (Fig. 5), the elongation of the falling limb in relation to the rising limb decreases with time into the melt season. This is supported by falling values of both dispersivity and the dispersion coefficient (Table 2), with the exception of experiment A7, for which dispersivity experiences a fourfold increase compared to experiment
A4. A7 was the highest elevation at which dye was injected, which likely explains the increase in dispersivity despite being late in the melt season (Fig. 7b). We interpret the decrease in dispersivity over time (Table 2) as an increase in drainage system efficiency, despite a general decrease in discharge and its diurnal cyclicity after peak discharge in late July (Fig. 3). We identify no significant relationship between dispersivity and either velocity or elevation (Fig. 7a, b), with $R^{2}$ values of 0.19 and 0.35 respectively. We do, however, identify a positive relationship between dispersivity and storage retardation (Fig. 7e), with an $R^{2}$ value of 0.85 , relating the spreading rate of dye to the temporary storage of dye in the system.

\section{Discussion}

\subsection{Meltwater flow regimes}

We propose that clustering of the values of the variables throughflow velocity, storage retardation, elevation, discharge, and dispersivity (Figs. 6, 7), in concert with breakthrough curve form (Fig. 5), indicates the existence of four distinct meltwater flow regimes, as summarized in Fig. 8. Regime 1 encompasses experiments $\mathbf{J} 1$ and $\mathbf{J} 2$, which are characterized by both high dispersivity, relatively high throughflow velocities despite occurring earliest in the field season, and high storage retardation, and are representative of relatively low drainage system efficiency. The velocity values may imply channelized but sinuous flow, possibly impeded by interaction with basal sediments down the relatively long flow pathways, resulting in noisy, multi-peaked breakthrough curves (Fig. 5). Regime 2 is represented solely by experiment $\mathrm{J} 3$, which depicts a large decrease in dispersivity and an increase in system efficiency, 17 days after experiment $\mathbf{J} 2$. The breakthrough curve for $\mathrm{J} 3$ is single peaked, but the elongated falling limb indicates temporary storage of dye, albeit less than for regime 1 . The northernmost stream through which the July experiments likely exited the glacier is very turbid. Interaction with basal sediments may contribute to the high storage retardation characteristic of regimes 1 and 2 .

Regime 3 contains experiments A1, A2 and A4, which are the three lowest elevation experiments, characterized by 

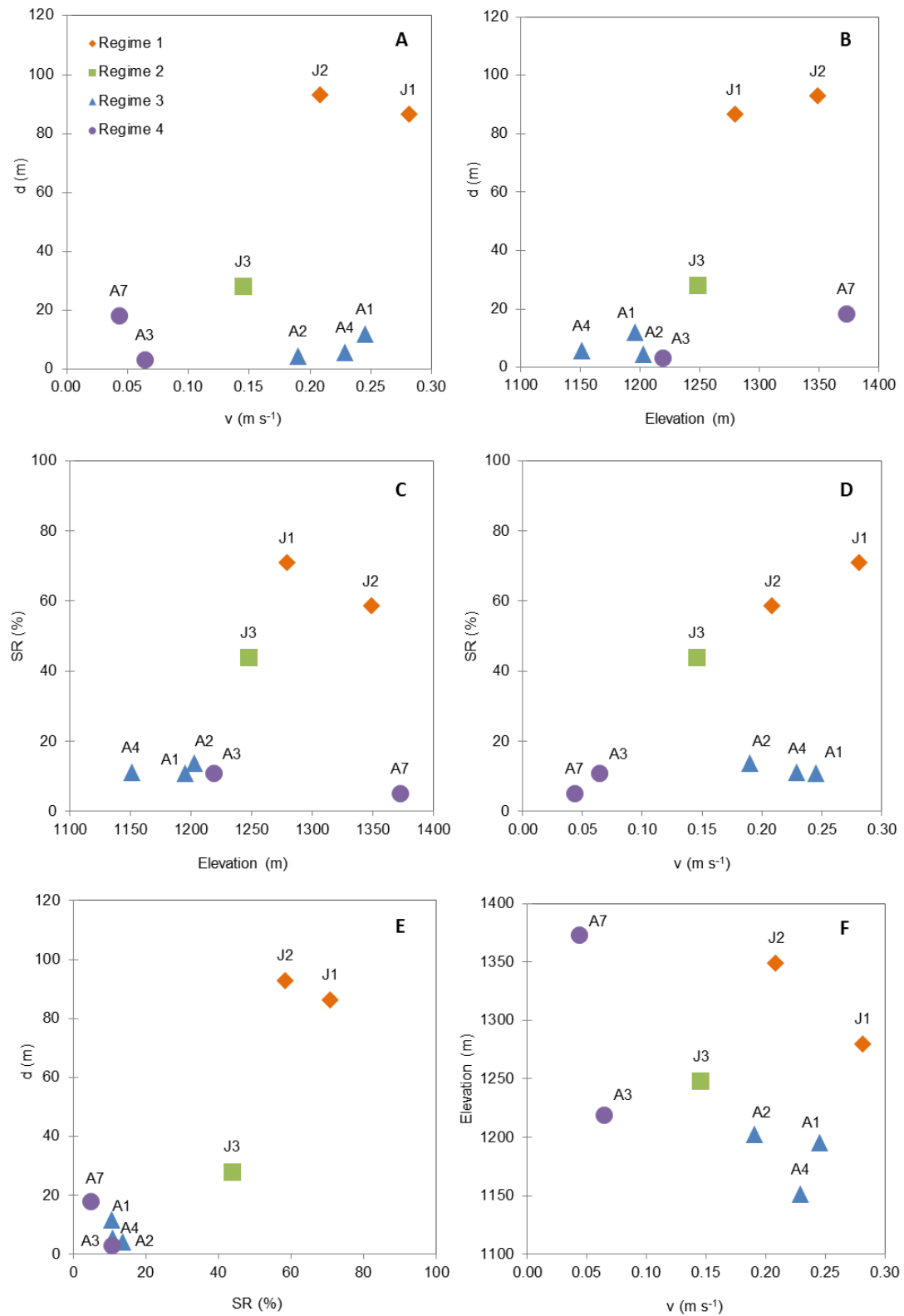

Figure 7. Plots showing the interaction between the variables: dispersivity $(d)$, throughflow velocity $(v)$, elevation and storage retardation (SR). Meltwater flow regimes 1, 2, 3 and 4 are depicted by orange diamonds, green squares, blue triangles and purple circles respectively.

low dispersivity, low storage retardation and high throughflow velocities (Figs. 7, 8). Flow through these moulins has the shortest travel pathway through the system, with dye injected at relatively low elevation late into the ablation season, into a system relatively high in discharge. Breakthrough curves in regime 3 are all single peaked and very narrow (Fig. 5), which combined with the characteristics summarized in Fig. 8 indicate a high degree of drainage system efficiency. Experiments A3 and A7 fall under flow regime 4, characterized by low throughflow velocities, low storage retardation, low dispersivity and relatively low discharge. The form of the breakthrough curves for A3 and A7 is sin- gle peaked, which supports channelized flow, despite low throughflow velocities. Injection point A3 is located just upglacier of moulins used for experiments $\mathrm{A} 1, \mathrm{~A} 2$ and $\mathrm{A} 4$ (regime 3). Despite this, there is a considerable increase in residence time for experiment $\mathrm{A} 3$; at least $2.5 \mathrm{~h}$ longer than for experiments within regime 3 . The residence time of A7 is the longest of the successful experiments, at ca. $14 \mathrm{~h}$, characterized by a broad yet single-peaked breakthrough curve (Fig. 5).

When comparing selected attribute pairs for experiments A3 and A7 (Fig. 8), the only variable for which clustering is not produced is elevation, suggesting a long operating path- 


\begin{tabular}{cccccc}
\hline Flow regime & Elevation & $\begin{array}{c}\text { Throughflow } \\
\text { velocity }\end{array}$ & Dispersivity & $\begin{array}{c}\text { Storage } \\
\text { retardation }\end{array}$ & Discharge \\
\hline 1 & high & high & high & high & n/a \\
2 & moderate & moderate & low & moderate & n/a \\
3 & low & high & low & low & high \\
4 & not clustered & low & low & low & low \\
\hline
\end{tabular}

Figure 8. Characteristics of meltwater flow regimes 1 to 4 , where high, moderate and low are relative to measured values. Variables for which values did not fall within the same classification are indicated as "not clustered".

way between these two injection points (Fig. 2). We interpret the behaviour depicted by the breakthrough curve of experiment A7 as reflecting subglacial/englacial meltwater storage followed by periodic release through an efficient system, addressing contemporaneous long residence time, low throughflow velocity, low dye recovery, yet a single-peaked dye breakthrough curve with low storage retardation. Only 6 days passed between the experiments in regime 3 and experiment $\mathrm{A} 7$, and experiment $\mathrm{A} 3$ was conducted on the same afternoon as experiment A4 in regime 3; thus, the distinction between these two regimes is spatial, and not temporal. Analysis of throughflow velocities against discharge (Fig. 6, Table 3) indicated that backing up of water may occur within the hydrological system of Rabots glaciär to accommodate discharge within a system, decreasing in sinuosity with distance downstream, resulting in an increased hydraulic gradient with elevation. We may then expect that a pressurized system still existed late into the season at the locations of experiments in regime 4, resulting in the observed low throughflow velocities (Fig. 8), while dye injections within regime 3 entered a low-pressure system with fast meltwater flow.

\subsection{Meltwater storage}

The temporary storage of dye can be viewed as an influencing factor on dispersion (Fig. 7e), which manifests itself as an elongation in the falling limb of modelled breakthrough curves (Fig. 5; Willis et al., 2009; Cowton et al., 2013). With the exception of experiment $\mathrm{A} 7$, we observe a $60 \%$ reduction in storage retardation in glacier-based dye tracer tests over time (Table 2). The largest storage values correspond to the more complex breakthrough curves from the July experiments, relating to high dispersivity and a less efficient drainage system. As throughflow velocities experienced no increase with time, we propose that the reduction in storage retardation over time relates to increasing efficiency, and decreasing sinuosity, rather than evolution from a true distributed system to a channelized system, which had likely already formed due to early onset of melting in 2013. Similar behaviour was reported by Cowton et al. (2013) for the Leverett Glacier, southwestern Greenland. Low dye recovery was calculated for experiments A2 and A4. Uranine was used as a tracer in these experiments; thus, low dye recovery is likely accounted for by photochemical decay of the dye between emergence from the glacier terminus and detection by the fluorometer downstream.

Combined with a very low dye recovery (Table 2), the mechanism of storage and release proposed to explain the return curve of experiment A7 may be indicative of storage in the englacial system (Fountain, 1993; Cowton et al., 2013). In this case, quantities of the injected dye, which become dilute as more meltwater enters the system, may be released periodically under pressure, resulting in a low dye recovery and a broad, single-peaked breakthrough curve. This hypothesis is strengthened by the $5 \%$ storage retardation calculated for automated sampling during the experiment (Table 2). Sporadic detection of hydrocarbons in the proglacial system (Rosqvist et al., 2014), rather than continuous emergence of pollutants, further attests to periodic release of meltwater and pollutants stored within the englacial/subglacial hydrological system. The stream in which dye emergence from experiment A7 was detected through manual water sampling has a very low turbidity in comparison to its northern counterpart, allowing us to further hypothesize that meltwater emerging in the southern proglacial outlet interacts with the bed to a lesser degree, and is possibly routed downstream for a long distance within the englacial system. Low recovery rates for both manual and automated sampling of experiment A7 may be exacerbated by refreezing of dye onto the ice since dye detection continued overnight, during falling temperatures and very low discharge.

With the exception of experiment D1, proglacial dye experiments for production of a rating curve resulted in recovery of at least $78 \%$ of the dye, with sorption to sediment particles likely to contribute to this result. Storage retardation varied between 18 and $38 \%$, and for three of these experiments storage retardation exceeded the percentage of dye that was not recovered. This overestimation of storage retardation may partly be attributed to the advection-dispersion model, which was adjusted for best fit to the measured breakthrough curve, and for which only the falling limb is considered when computing storage retardation. The presence of dye from previous experiments within the braided proglacial system, mobilized in periods of increased water level and discharge, may also affect recovery of dye, as could fluorescence from suspended sediments at the same wavelength as RWT (Cowton et al., 2012).

\subsection{Implications for transport of pollutants}

Kerosene fractions that remain in the initial source zone (Fig. 1) after surface volatilization (Jarsjö et al., 1994) can potentially dissolve into and move with meltwater through Rabots glaciär. Extensive plumes of dissolved contaminants often develop down-gradient of hydrocarbon source zones due to advection, as for instance shown through monitoring of numerous spills in industrial areas (e.g. Jarsjö et al., 
2005). The distribution of advective travel times derived from tracer experiments provides an essential basis in quantifying governing transport and attenuation-retention processes for kerosene dissolved in meltwater, which previously have been shown for large-scale spreading of dissolved contaminants in non-glaciated environments (Darracq et al., 2010; Destouni et al., 2010).

In this context, current results provide a first quantification of the large difference in transport conditions between the hydrocarbon-polluted Rabots glaciär and well-documented cases of hydrocarbon pollution in groundwater near industrial areas; most notably, the throughflow velocities ( 0.04 to $0.28 \mathrm{~m} \mathrm{~s}^{-1}$ ) of Rabots glaciär are at least 2 orders of magnitude higher than typical advective travel times in contaminated sand aquifers of Europe (Jarsjö et al., 2005). Whereas this means risk of rapid spreading to downstream waters, the existence of flow regimes characterized by relatively low tracer recovery and high storage retardation also implies that part of the dissolved kerosene may be retained in Rabots glaciär for extended periods of time. In addition, surplus kerosene from the initial source zone may potentially move with water in free (non-dissolved) phase into the drainage system of the glacier; for instance, relatively light hydrocarbon mixtures like kerosene will float on top of watersaturated zones (e.g. Schwille, 1981). The Rabots glaciär proglacial river forms part of the source of the Kalix River, which extends for ca. $460 \mathrm{~km}$ before reaching the Bothnian Sea, running through a number of settlements. Low tracer recovery described in this study and the sporadic detection of low hydrocarbon concentrations in the proglacial river (Rosqvist et al., 2014) suggests little or no risk to water consumption in downstream settlements. The extent to which accumulation of pollutants within Rabots glaciär and its hydrological catchment may affect the local environment requires further monitoring to assess.

\section{Conclusions}

The results of dye tracing experiments provide a first look into the internal hydrological system of Rabots glaciär, offering a new insight into both the properties and transit times of meltwater flow through the glacier. In response to an early start to the melt season, development of efficient drainage began in July, with return curves supporting increased efficiency and decreasing sinuosity throughout August. Analysis of proglacial discharge and turbidity attests further to formation of efficient subglacial drainage, with clockwise hysteresis supporting easy mobilization of sediments readily available within channels, thus also any pollutants that may have sorbed onto sediments. More extensive dye tracing studies are necessary to explore the full seasonal evolution of the Rabots glaciär hydrological system. Nevertheless, this study provides a first insight into the drainage system topology, which should be explored further in future studies in con- cert with an investigation of the internal thermal structure of the glacier. Although limited in number, the results of these experiments suggest that in comparison to Storglaciären, the internal hydrological system of Rabots glaciär is characterized by a degree of homogeny in efficiency over a larger altitudinal extent, although constrained and divided laterally by the ice flow and structure of the glacier.

Assuming flow of pollutants in solution with meltwater, the delayed but efficient form of breakthrough curve A7, combined with a very low dye return, indicates that pollutants are being periodically released from an englacial/subglacial store after entering the internal glacier hydrological system near the source zone. This is supported by sporadic rather than continuous detection of hydrocarbons in the proglacial river system. Experiment A7, originating directly downstream of the source zone, estimates a transit time of ca. $14 \mathrm{~h}$ for transport through the full englacial/subglacial hydrological system. By mid-August, the drainage system is well developed, producing efficient breakthrough of dye, even for experiment A7, which originated above $1350 \mathrm{~m}$ a.s.l. and at a very short distance from the remaining snowpack. Snow is relatively permeable in comparison to underlying firn and ice, and unlikely to retain pollutants at the multi-year scale, but pollutants stored within the firn layer and ice mass will continue to be released gradually by ablation processes during future melt seasons. Storage within firn and ice, and within the internal hydrological system as demonstrated here, provides an opportunity for refreezing, further increasing the permanence of pollutants in the glacier system. The results presented here offer an important insight into the transport of pollutants through a full glacier system, contributing towards a broader analysis of the spread, longevity and impact of hydrocarbon pollutants in the Rabots glaciär hydrological catchment.

Author contributions. C. C. Clason led and all other authors contributed to the writing of the manuscript. Fieldwork was conducted by all authors, C. C. Clason designed the glacier hydrological experiments, and C. Coch and C. C. Clason analysed the data and prepared figures.

Acknowledgements. This work was funded in 2012 by Formas (grant number BR9912A to G. Rosqvist) and Statens Fastighetsverk. We wish to thank T. Karlin, S. Ingvander, A. LaBianca, A. Mercer, P. Eriksson and V. Plevrakis for their help in instrumentation set-up and data collection in the field, and P. Holmlund for providing imagery. We also wish to thank C. Helanow, M. Pelto and two anonymous reviewers for their comments which helped to improve the manuscript. K. Brugger gratefully acknowledges financial support from the University of Minnesota, Morris' Faculty Research Enhancement Funds.

Edited by: A. Ghadouani 


\section{References}

Bingham, R. G., Nienow, P., Sharp, M. J., and Boon, S.: Subglacial drainage processes at a High Arctic polythermal valley glacier, J. Glaciol., 51, 15-24, doi:10.3189/172756505781829520, 2005.

Bjornsson, H.: Radio-echo sounding maps of Storglaciären, Isfallsglaciären and Rabots glaciär, northern Sweden, Geogr. Ann. A, 63, 225-231, 1981.

Brugger, K. A.: The non-synchronous response of Rabots Glaciär and Storglaciären, northern Sweden, to recent climate change: a comparative study, Ann. Glaciol., 46, 275-282, doi:10.3189/172756407782871369, 2007.

Brugger, K. A. and Pankratz, L.: Changes in the Geometry and Volume of Rabots glaciär, Sweden, 2003-2011: Recent Accelerated Volume Loss Linked to More Negative Summer Balances, Geogr. Ann. A, doi:10.1111/geoa.12062, 2014.

Brugman, M. M.: Water flow at the base of a surging glacier, $\mathrm{PhD}$ thesis, California Institute of Technology, 1986, unpublished.

Chandler, D. M., Wadham, J. L., Lis, G. P., Cowton, T., Sole, A., Bartholomew, I., Telling, J., Nienow, P., Bagshaw, E. B., Mair, D., Vinen, S. and Hubbard, A.: Evolution of the subglacial drainage system beneath the Greenland Ice Sheet revealed by tracers, Nat. Geosci., 6, 195-198, 2013.

Cowton, T., Nienow, P., Bartholomew, I., Sole, A., and Mair, D.: Rapid erosion beneath the Greenland ice sheet, Geology, 40, 343-346, 2012.

Cowton, T., Nienow, P., Sole, A., Wadham, J., Lis, G., Bartholomew, I., Mair, D., and Chandler, D.: Evolution of drainage system morphology at a land-terminating Greenlandic outlet glacier, J. Geophys. Res., 118, 1-13, doi:10.1029/2012JF002540, 2013.

Darracq, A., Destouni, G., Persson, K., Prieto, C., and Jarsjö, J.: Quantification of advective solute travel times and mass transport through hydrological catchments, Environ. Fluid Mech., 10, 103-120, 2010.

Destouni, G., Persson, K., Prieto, C., and Jarsjö, J.: General quantification of catchment-scale nutrient and pollutant transport through the subsurface to surface and coastal waters, Environ. Sci. Technol., 44, 2048-2055, 2010.

Fountain, A. G.: Geometry and flow conditions of subglacial water at South cascade glacier, Washington state, USA; an analysis of tracer injections, J. Glaciol., 30, 180-187, 1993.

Fountain, A. G., Jacobel, R. W., Schlichting, R., and Jansson, P.: Fractures as the main pathways of water flow in temperate glaciers, Nature, 433, 618-621, 2005.

Glasser, N. F., Hambrey, M. J., Etienne, J. L., Jansson, P., and Pettersson, R.: The origin and significance of debris-charged ridges at the surface of Storglaciären, northern Sweden, Geogr. Ann. A, 85, 127-147, 2003.

Hock, R. and Hooke, R. L.: Evolution of the internal drainage system in the lower part of the ablation area of Storglaciären, Sweden, Geol. Soc. Am. Bull., 105, 537-546, doi:10.1130/00167606(1993)105<0537:EOTIDS> 2.3.CO;2, 1993.

Hodgkins, R.: Seasonal trend in suspended-sediment transport from an Arctic glacier, and implications for drainage-system structure, Ann. Glaciol., 22, 147-151, 1996.

Holmlund, P.: Internal geometry and evolution of moulins, Storglaciären, Sweden, J. Glaciol., 34, 242-248, 1988.

Hooke, R. LeB., Miller, S. B., and Kohler, J.: Character of the englacial and subglacial drainage system in the upper part of the ablation area of Storglaciaren, Sweden, J. Glaciol., 34, 228-231, 1988.

Hubbard, B. and Nienow, P.: Alpine subglacial hydrology, Quaternary Sci. Rev., 16, 939-955, 1997.

Jansson, P.: Dynamics and hydrology of a small polythermal valley glacier, Geogr. Ann. A, 78, 171-180, 1996.

Jarsjö, J., Destouni, G., and Yaron, B.: Retention and volatilisation of kerosene: laboratory experiments on glacial and post glacial soils, J. Contam. Hydrol., 17, 167-185, 1994.

Jarsjö, J., Bayer-Raich, M., and Ptak, T.: Monitoring groundwater contamination and delineating source zones at industrial sites: Uncertainty analyses using integral pumping tests, J. Contam. Hydrol., 79, 107-134, 2005.

Karlén, W.: Holocene glacier and climatic variations, Kebnekaise mountains, Swedish Lapland, Geogr. Ann. A, 55, 29-63, 1973.

Kohler, J.: Determining the extent of pressurized flow beneath Storglaciären, Sweden, using results of tracer experiments and measurements of input and output discharge, J. Glaciol., 41, 217231, 1995.

Leopold, L. B. and Maddock, T. J.: The hydraulic geometry of stream channels and some physiographic implications, USGS Professional Paper, 252 pp., 1954.

Nienow, P. W.: Dye tracer investigations of glacier hydrological systems, PhD thesis, Cambridge University, UK, 1993.

Nienow, P.: Dye Tracer Investigations of Glacier Hydrology, edited by: Singh, V. P., Singh, P., and Haritashya, U. K., in: Encyclopedia of Snow, Ice and Glaciers, Springer, Netherlands. 242-245, doi:10.1007/978-90-481-2642-2_126, 2011.

Nienow, P. W., Sharp, M., and Willis, I. C.: Sampling-rate effects on the properties of dye breakthrough curves from glaciers, J. Glaciol., 42, 184-189, 1996.

Nienow, P., Sharp, M., and Willis, I.: Seasonal changes in the morphology of the subglacial drainage system, Haut Glacier d'Arolla, Switzerland, Earth Surf. Proc. Land., 23, 825-843, doi:10.1002/(SICI)1096-9837(199809)23:9< 825::AID-ESP893> 3.0.CO;2-2, 1998.

Nilsson, J. and Sundblad, B.: The internal drainage of Storglaciären and Isfallsglaciären described by an autoregressive model, Geogr. Ann. A, 57, 73-98, 1975.

Pietrón, J., Jarsjö, J., Romanchenko, A. O., and Chalov, S. R.: Model analyses of the contribution of in-channel processes to sediment concentration hysteresis loops, J. Hydrol., 527, 576589, 2015.

Pohjola, V. A.: TV-video observations of englacial voids in Storglaciären, Sweden, J. Glaciol., 40, 231-240, 1994.

Riihimaki, C. A., MacGregor, K. R., Anderson, R. S., Anderson, S. P., and Loso, M. G.: Sediment evacuation and glacial erosion rates at a small alpine glacier, J. Geophys. Res., 110, F03003, doi:10.1029/2004JF000189, 2005.

Rosqvist, G., Jarsjö, J., and Clason, C.: Redovisning av 2013 års övervakning av utveckling och spridning av flygbränsle och oljeföroreningar i Kebnekaise efter Herculesolyckan 15 mars 2012, Tarfala Research Station report, 26 pp., 2014.

Schneider, T.: Water movement in the firn of Storglaciären, Sweden, J. Glaciol., 45, 286-294, doi:10.3189/002214399793377211, 1999.

Schuler, T.: Investigation of water drainage through an alpine glacier by tracer experiments and numerical modelling, $\mathrm{PhD}$ the- 
sis, Swiss Federal Institute of Technology, Zürich, Switzerland, 2002.

Schuler, T., Fischer, U. H., and Gudmundsson, G. H.: Diurnal variability of subglacial drainage conditions as revealed by tracer experiments, J. Geophys. Res., 109, F02008, doi:10.1029/2003JF000082, 2004.

Schwille, F.: Groundwater pollution in porous-media by fluids immiscible with water, Sci. Total Environ., 21, 173-185, 1981.

Schytt, V.: The net mass balance of Storglaciaren, Kebnekaise, Sweden, related to the height of the equilibrium line and to the height of the $500 \mathrm{mb}$ surface, Geogr. Ann. A, 63, 219-223, 1981.

Seaberg, S. Z., Seaberg, J. Z., Hooke, LeB, R., and Wiberg, D. W.: Character of the englacial and subglacial drainage system in the lower part of the ablation area of Storglaciären, Sweden, as revealed by dye-trace studies, J. Glaciol., 34, 217-227, 1988.

Singh, P., Haritashya, U. K., Ramasastri, K. S., and Kumar, N.: Diurnal variations in discharge and suspended sediment concentration, including runoff-delaying characteristics, of the Gangotri Glacier in the Garhwal Himalayas, Hydrol. Process., 19, 14451457, 2005.

Stenborg, T.: Problems concerning winter run-off from glaciers. Geog. Ann. A., Phys. Geogr., 47, 141-184, 1965.
Stenborg, T.: Studies of the internal drainage of glaciers, Geog. Ann. A., 51, 13-41, 1969.

Stenborg, T.: Some viewpoints on the internal drainage of glaciers, Symposium on the Hydrology of Glaciers, Cambridge, 7-13 September 1969, organized by the Glaciological society, IAHS Publication 95, 117-130, 1973.

Theakstone, W. H. and Knudsen, N. T.: Dye tracer tests of water movement at the glacier Austre Okstindbreen, Norway, Norsk Geograf. Tidsskr., 35, 21-28, doi:10.1080/00291958108621970, 1981.

Willis, I. C., Sharp, M. J., and Richards, K. S.: Configuration of the drainage system of Midtdalsbreen, Norway, as indicated by dye-tracing experiments, J. Glaciol., 36, 89-101, 1990.

Willis, I. C., Lawson, W., Owens, I., Jacobel, B., and Autridge, J.: Subglacial drainage system structure and morphology of Brewster Glacier, New Zealand, Hydrol. Process., 23, 384-396, doi:10.1002/hyp.7146, 2009.

Willis, I. C., Fitzsimmons, C. D., Melvold, K., Andreassen, L. M., and Giesen, R. H.: Structure, morphology and water flux of a subglacial drainage system, Midtdalsbreen, Norway, Hydrol. Process., 26, 3810-3829, doi:10.1002/hyp.8431, 2012. 